aspect of management-besides many others-their study differed from ours; in our series half of the deliveries were conducted with Bracht's manoeuvre.

Given adequate management based on the principle of selective caesarean section, the belief that to be born by the breech is highly dangerous appears to be untenable. Arguably either a better selection or a higher section rate might have reduced the slight functional impairment that did occur in the breech-born children in our series. It should be remembered, however, that this may well have been caused by variables other than breech delivery. From our results we see no reason to advocate a higher section rate, though we think that selection might well have been better, both for caesarean section and for vaginal delivery.

The concept of breech delivery as a highly dangerous event probably stems from two origins-firstly, the high rate of pregnancy complications and fetal abnormalities associated with breech position, which results in high perinatal mortality and morbidity; and, secondly, the fact that even an accepted vaginal breech delivery may very well in rare cases be difficult and result in severe birth trauma. The danger associated with breech position, however, should not be projected on the mechanics of birth in breech presentation.

This study is part of the Groningen Perinatal Project and was supported by the Dr W M Phelpsstichting, the Netherlands.

\section{References}

1 Alexopoulos KA. The importance of breech delivery in the pathogenesis of brain damage. Clin Pediatr (Phila) 1973;12:248-9.
2 Kolmorgen K von, Seidenschnur G, Rissmann M. Kritische Anmerkung zur Geburtsleitung und perinatalen Mortalität bei BeckenendlagenEinlingsgeburten. Zentralbl Gynaekol 1975;97:1426-34.

${ }^{3}$ Kubli F, Rüttgers H, Meyer-Menk M. Die fetale Azidosege-fährdung bei vaginaler Geburt aus Beckenendlage. $Z$ Geburtshilfe Perinatol 1975;179: $1-16$.

${ }^{4}$ Dunn PM. Breech delivery-perinatal morbidity and mortality. In: Rooth G, Bratteby LE, eds. Perinatal medicine. Stockholm: Almqvist and Wiksell International, 1976:57-60.

5 Touwen BCL, Prechtl HFR. The neurological examination of the child with minor nervous dysfunction. Clinics in Developmental Medicine $1970 ;$ No 58.

6 Touwen BCL. Examination of children with minor neurological dysfunction. Clinics in Developmental Medicine 1979; No 71.

${ }^{7}$ Dijkstra J. Thesis. De prognostische betekenis van neurologische afwijkingen bij pasgeboren kinderen. Groningen University, 1960.

${ }^{8}$ Jurgens-van der Zee AD, Bierman-van Eendenburg MEC, Fidler VJ, et al. Preterm birth, growth retardation and acidemia in relation to neurological abnormality of the newborn. Early Hum Dev 1979;3:141-54.

9 Berendes HW. Obstetrical complications and mental deficiency. International Copenhagen congress on the scientific study of mental retardation. Vol 1. Copenhagen, 1964:308-16.

${ }^{10}$ Bishop EH, Israel SL, Briscoe CC. Obstetric influence on the premature infant's first year of development. A report from the collaborative study of cerebral palsy. Obstet Gynecol 1965;26:628-35.

${ }^{11}$ Neligan GA. The quality of the survivors of breech delivery in a geographically defined population. In: Rooth G, Bratteby LE, eds. Perinatal medicine. Stockholm: Almqvist and Wiksell International, 1976:61-4.

1: Hochuli E, Dubler O, Bornhauser E, Schoop E. Die kindliche Entwicklung nach vaginaler und Abdominaler Entbindung bei Beckenendlagen. Geburtshilfe Frauenheilkd 1977;37:4-11.

${ }^{3}$ Manzke H, Mau G, Ondarza-Landwehr G von, et al Prospective Langzeituntersuchung von Beckenendlage-Kindern. In: Schmidt E, Dudenhausen JW, Saling E, eds. Perinatal medizin. Vol 7. Stuttgart: Thieme, 1978:127-40.

14 Collea JV, Rabin SC, Weghorst GR, Quilligan EJ. The randomized management of term frank breech presentation: vaginal delivery vs caesarean section. Am $\mathcal{F}$ Obstet Gynecol 1978;131:186-95.

\title{
Laser treatment for carcinoma of the bronchus
}

\author{
M R HETZEL，F J C MILLARD， R AYESH，C E BRIDGES， E M NANSON, C P SWAIN, \\ I P WILLIAMS
}

\begin{abstract}
Laser treatment in carcinoma of the bronchus is essentially palliative and is suitable for only a few patients. Patients selected for laser treatment must have predominantly endobronchial growth with normal bronchial anatomy still identifiable and symptoms due to the obstruction or to haemoptysis. A total of 34 patients with carcinoma of the bronchus were treated with argon gas or neodynium yttrium aluminium garnet crystal lasers. Good palliation was obtained in just over half the cases of partial obstruction of the trachea or main bronchus, but best results were obtained in lesions of the trachea or
\end{abstract}

\footnotetext{
University College Hospital, London WC1E 6AU and Whittington Hospital, London N19 5JG

M R HETZEL, MD, MRCP, consultant chest physician

R AYESH, MD, research fellow

C P SWAIN, MB, MRCP, research fellow

St James's Hospital, Balham, London SW12 8HW

F J C MILLARD, MD, FRCP, consultant physician

C E BRIDGES, BSC, senior physicist

E M NANSON, $\mathrm{MB}, \mathrm{BCH}$, research fellow

I P WILLIAMS, MB, MRCP, senior registrar
}

main carina. Re-expansion of the collapsed lung was achieved in some cases but with considerable risk of pneumonia. Haemoptysis was controlled at least partly in several cases.

Laser treatment has the advantage of having no toxicity or dose limit and may be used in cases of poor respiratory function. The procedure was better tolerated than radiotherapy or chemotherapy and its relatively lower cost may justify setting up laser units in major cities.

\section{Introduction}

Though there have been some improvements in recent years in the treatment of bronchial carcinoma, most patients can hope only for a brief prolongation of survival and palliation of symptoms. The side effects of radiotherapy and chemotherapy may be severe and their toxicity limits their usefulness. We believe there is therefore a place for new methods of treatment of bronchial carcinoma, even if these are only intended for palliation, providing they are well tolerated and have few side effects. Laser treatment potentially fulfils these requirements. In early 1980 we set out to modify a laser system, originally intended for gastroenterological use, for the fibreoptic bronchoscope. We have also used this system for other non-malignant 
tracheobronchial conditions, but our prime interest was in treatment of bronchial carcinoma. We discuss the principles and assess the effectiveness of laser treatment in bronchial carcinoma.

\section{Patients and methods}

Patients were selected in whom predominantly intraluminal tumour was causing severe breathlessness: in some cases, tumour had caused total collapse of a lung. We also studied patients with intractable haemoptysis from endobronchial growth. Most patients had previously suffered relapse after conventional treatment with surgery, radiotherapy, or chemotherapy or, in a few cases, were unsuitable for standard treatment. We therefore included only patients with inoperable tumours, which were predominantly localised and accessible to the bronchoscope, in whom metastatic disease, if present, was causing only minor symptoms in comparison with breathlessness or haemoptysis. There was no age limit and all cell types of tumour were accepted.

A total of 34 patients were selected, and all were assessed by chest $x$-ray examination, visual analogue scores of their impression of the severity of their breathlessness and general health, Karnofsky performance index, ${ }^{1}$ and the Medical Research Council's grading of breathlessness ${ }^{2}$ before laser treatment. The peak expiratory flow rate, forced expiratory volume in $1 \mathrm{~s}$, and vital capacity were measured from the flow volume loop, the inspiratory part of which is of particular value in assessing upper airways obstruction. ${ }^{3}$ Serial four-hourly peak flow measurements were recorded with a Wright peak flow meter while patients were in hospital. Exercise tolerance was measured by the six-minute walking test. ${ }^{4}$ The severity of haemoptysis, including its frequency and amount, was judged as accurately as possible from the history, and patients kept diary cards of any subsequent haemoptysis The extent of tumour seen at bronchoscopy was recorded on charts of the bronchial tree and by endoscopic photography.

Treatments were initially given every three to seven days until a satisfactory response was obtained. Laser treatment was abandoned if there was no improvement after three sessions. Patients showing initial response to treatment were followed up with further bronchoscopies and laser treatment at monthly intervals and, if improvement was maintained, these intervals were increased to a maximum of three months. Laser treatment was subsequently abandoned if a relapse could not be controlled by a maximum of three further treatments at intervals of three to seven days, or when the severity of metastatic disease outweighed the potential benefits of continued treatment. The protocol of symptom scores, $x$-ray examinations, and physiologica tests was repeated cvery week during initial treatment and before all subsequent bronchoscopies. It was not practicable to adhere strictly to this protocol for patients who lived a long way from London; in these cases referring clinicians were asked to carry out as much of the follow-up protocol as possible and to refer patients back for further laser treatment if indicated. When patients eventually died, postmortem data were requested and obtained whenever possible.

Patients were considered to have a good response to laser treatment if there was a symptomatic improvement and also an objective improvement in respiratory function. Patients whose assessment of symptoms indicated improvement, but who had no improvement in respiratory function tests, were classified as partial responders.

Figure 1 shows the main components of the laser system used. Early work from March 1980 to May 1981 was with an argon gas laser (Spectra Physics), producing a visible blue laser beam wavelength $0.514 \mu \mathrm{m}$, maximum output 12 watts, transmitted through a $200 \mu \mathrm{m}$ quartz fibre (Quartz Celice). Later work was with neodynium yttrium aluminium garnet crystal lasers, which produce an invisible, near infrared laser beam, wavelength $1.06 \mu \mathrm{m}$, maximum output $70-100$ watts (Barr and Stroud Fiberlase 100 lasers at St James's and University College Hospitals; MBB-AT Medilas laser at Whittington Hospital). This is delivered through a $600 \mu \mathrm{m}$ glass (Barr and Stroud) or quartz (Medilas) fibre. The laser light is transmitted by internal reflection through the fibre and, because there is no lens on its distal end, emerges with a divergent beam of about $10^{\circ}$. Power density therefore falls off rapidly with distance from the fibre tip; this is a useful safety feature. The power output (watts) and duration of the laser irradiation (seconds) may be varied, but the tissue damage is determined only by the total energy delivered (joules) ${ }^{5}$ and varies little over an effective operating distance of $1-1.5 \mathrm{~cm}$ from the fibre tip. The argon laser light has a lower penetration than the neodynium yttrium aluminium garnet crystal laser, which dissipates its energy to a depth of some $6 \mathrm{~mm}$. Blood and mucus on the tumour surface will absorb energy so that there is less damage to the tumour itself. The argon laser is particularly impaired by surface bleeding because of its high affinity for blood.

The fibre tip must be kept scrupulously clean. Any tissue or mucus that touches it will absorb the energy of the emerging light, raising it to very high temperatures, and chipping the fibre tip: this disperses the laser beam with loss of power and further damage to the fibre. These problems are reduced by enclosing the fibre in a Teflon tube through which gas is blown. A metal ferrule holds the fibre tip in the centre of the gas stream. Compressed air at a flow rate of $30 \mathrm{ml} / \mathrm{s}$ is blown continually through the catheter and this increases to flow rates of up to $80 \mathrm{ml} / \mathrm{s}$ when the laser is fired. A mixture of $80 \%$ helium and $20 \%$ oxygen will achieve higher flow rates through this high resistance

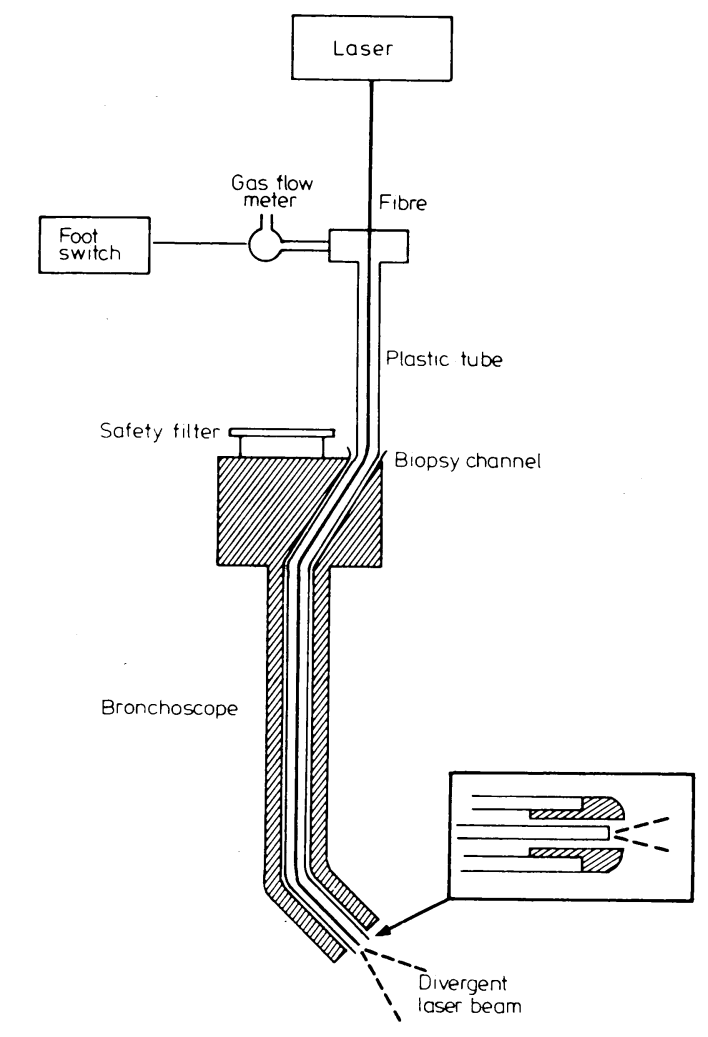

FIG 1-Fibreoptic bronchoscope with laser fibre passing down suction channel.

system but, in practice, we have not found that this is any more effective than air.

The fibre/catheter system is passed through the bronchoscope suction channel. The neodynium yttrium aluminium garnet crystal lasers can be used only in wide channel bronchoscopes (Olympus BF1 TR), the narrower argon system will fit a standard $2 \mathrm{~mm}$ biopsy channel. The laser beam is guided on to the tumour target by manipulating the bronchoscope, using an aiming beam. In the argon laser this is achieved by diverting all but $1 \%$ of the laser output into a heat sink so that the residual beam may be observed directly as a blue spot. The neodynium yttrium aluminium garnet crystal beam is invisible and a red aiming beam is produced by a low-power helium-neon laser, coaxial with the neodynium yttrium aluminium garnet crystal beam. A foot switch is depressed to operate the full power of the laser and increase gas flow. In the argon system an electronically operated orange filter comes across the eyepiece to protect the bronchoscopist's eyes. With the neodynium yttrium aluminium garnet crystal system, an infrared filter may be incorporated permanently in the bronchoscope eyepiece as this does not impair normal vision or photography. Other personnel wear safety goggles. The fibre must be removed from the bronchoscope and cleaned if it becomes contaminated with debris or if suction is required. The fibre system may be fitted with safety interlocks so that the laser can be fired only when the fibre is in the instrument; this facility is currently available only for gastroscopes with the laser equipment which we used.

Power levels used varied somewhat as experience was gained. With the neodynium yttrium aluminium garnet crystal lasers we used 60-70 watts with pulse durations of 1-2 seconds. Lower power levels are preferable for control of haemoptysis. The condition of the 
fibre was checked before treatment by measuring the power of the beam at the fibre tip with a power meter. The total energy delivered in a treatment session is recorded in joules (watts $\times$ seconds).

Premedication and local anaesthesia are the same as for routine diagnostic bronchoscopy. Atropine $0.6 \mathrm{mg}$ and papaveretum (Omnopon) $10 \mathrm{mg}$ is followed by $4 \%$ lignocaine to the nose and pharynx and $2 \%$ lignocaine to the bronchial tree. Intravenous diazepam 5-10 mg is given before inserting the bronchoscope, and small doses of intravenous diamorphine are helpful in reducing the coughing induced by smoke when using the laser. In patients with lesions affecting the trachea or main carina, dexamethasone was given as a precautionary measure. After initial adverse experience in attempting to re-expand totally collapsed lungs beyond obstructing tumours (see results), metronidazole $400 \mathrm{mg}$ and amoxycillin $250 \mathrm{mg}$ were given thrice daily prophylactically to patients with total collapse of a lung or lobe. The nature of the laser treatment was explained to all patients, who gave their informed consent to the study. The protocol was approved by the ethics committees of all three hospitals.

\section{Results}

The table gives details of the 34 patients ( 18 men and 16 women, aged 54-79). Most had squamous cell carcinoma: 19 had partial obstruction of a major airway, nine had complete obstruction with collapse, and six were treated for recurrent haemoptysis.

\section{PARTIAL OBSTRUCTION}

Ten patients had a good response to treatment (symptomatic and objective improvement), four showed a partial response (symptomatic improvement only), and five died before any response was seen.

Case history (case No 9)-A 57 year old woman with an adenocarcinoma of the carina had previously been treated by radiotherapy. Recurrent tumour almost completely occluded the right main bronchus and partially occluded the left. She was breathless on talking. After treatment she was able to leave hospital carrying her suitcase and return to a light job. Her peak flow rose from $190 \mathrm{l} / \mathrm{min}$ to $360 \mathrm{l} / \mathrm{min}$. She died from metastatic disease three months later.

\section{COMPLETE OBSTRUCTION WITH COLLAPSE (NINE PATIENTS)}

Obstruction was relieved and re-expansion achieved in three cases, but two of these patients died from overwhelming infection. The third patient survived for five months but there was no symptomatic or objective improvement. In the remaining six patients the obstruction could not be relieved. No adverse effects were seen from failed treatment, however.

Case history (case No 21)-A 64 year old man had a poorly differentiated squamous cell carcinoma of the right main bronchus. He had improved after chemotherapy but the growth had recurred with complete occlusion of the bronchus and collapse of the right lung.

\begin{tabular}{|c|c|c|c|c|c|c|c|c|}
\hline Case No & Age & Sex & Site of lesion & Previous treatment & Laser & $\begin{array}{l}\text { No of } \\
\text { sessions }\end{array}$ & Response & $\begin{array}{c}\text { Survival after } \\
\text { first laser treat- } \\
\text { ment (weeks) } \dagger\end{array}$ \\
\hline \multicolumn{9}{|c|}{ Patients with partial obstruction of trachea. or main bronchus } \\
\hline$\frac{1}{2}$ & $\begin{array}{l}66 \\
56\end{array}$ & $\begin{array}{l}\mathrm{M} \\
\mathrm{F}\end{array}$ & $\begin{array}{l}\text { Left main bronchus } \\
\text { Trachea }\end{array}$ & Surgery & $\begin{array}{r}700 \mathrm{~J}(\mathrm{~A}) \\
5400 \mathrm{~J}(\mathrm{~A})\end{array}$ & $\begin{array}{l}2 \\
8\end{array}$ & $\begin{array}{l}\text { No change } \\
\text { Good PEFR } \\
(108-150)\end{array}$ & $\begin{array}{r}1 \\
26\end{array}$ \\
\hline $\begin{array}{l}3 \\
4 \\
5 \\
6\end{array}$ & $\begin{array}{l}62 \\
73 \\
76 \\
59\end{array}$ & $\begin{array}{l}\mathrm{F} \\
\mathrm{M} \\
\mathrm{F} \\
\mathrm{M}\end{array}$ & $\begin{array}{l}\text { Left main bronchus } \\
\text { Left main bronchus } \\
\text { Right main bronchus } \\
\text { Trachea }\end{array}$ & $\begin{array}{l}\text { Radiotherapy } \\
\text { Radiotherapy } \\
\text { Radiotherapy }\end{array}$ & $\begin{array}{l}1 \quad 800 \mathrm{~J}(\mathrm{~A}) \\
3 \text { 800J (A) } \\
1990 \mathrm{~J}(\mathrm{~A}) \\
8000 \mathrm{~J}(\mathrm{~A})\end{array}$ & $\begin{array}{l}5 \\
3 \\
5 \\
9\end{array}$ & $\begin{array}{l}\text { Partial } \\
\text { No change } \\
\text { Partial } \\
\text { Good PEFR } \\
(80-162)\end{array}$ & $\begin{array}{r}8 \\
8 \\
48 \\
8\end{array}$ \\
\hline 7 & 70 & $\mathrm{~F}$ & Carina & $\begin{array}{l}\text { Surgery } \\
\text { Radiotherapy } \\
\text { Chemotherapy }\end{array}$ & $2000 \mathrm{~J}(\mathrm{~A})$ & 4 & $\begin{array}{l}\text { Good PEFR } \\
(126-150)\end{array}$ & 13 \\
\hline $\begin{array}{l}8 \\
9\end{array}$ & $\begin{array}{l}54 \\
57\end{array}$ & $\stackrel{\mathrm{F}}{\mathrm{F}}$ & $\begin{array}{l}\text { Trachea } \\
\text { Carina }\end{array}$ & $\begin{array}{l}\text { Radiotherapy } \\
\text { Radiotherapy }\end{array}$ & $\begin{array}{l}7200 \mathrm{~J}(\mathrm{~A}) \\
7800 \mathrm{~J}(\mathrm{YAG})\end{array}$ & $\begin{array}{l}4 \\
7\end{array}$ & $\begin{array}{l}\text { No change } \\
\text { Good PEFP. } \\
(190-350)\end{array}$ & 22 \\
\hline $\begin{array}{l}10 \\
11\end{array}$ & $\begin{array}{l}76 \\
63\end{array}$ & $\begin{array}{l}\mathrm{M} \\
\mathrm{F}\end{array}$ & $\begin{array}{l}\text { Right main bronchus } \\
\text { Trachea }\end{array}$ & $\begin{array}{l}\text { Radiotherapy } \\
\text { Chemotherapy }\end{array}$ & $\begin{array}{l}8 \text { 200J (YAG) } \\
6300 \mathrm{~J}(\mathrm{YAG})\end{array}$ & $\begin{array}{l}5 \\
3\end{array}$ & $\begin{array}{c}\text { No change } \\
\text { Good PEFR } \\
(96-184)\end{array}$ & $\begin{array}{r}3 \\
21\end{array}$ \\
\hline $\begin{array}{l}12 \\
13\end{array}$ & $\begin{array}{l}59 \\
59\end{array}$ & $\begin{array}{l}M \\
M\end{array}$ & $\begin{array}{l}\text { Carina } \\
\text { Right main bronchus }\end{array}$ & Radiotherapy & $\begin{array}{l}22200 \mathrm{~J} \text { (YAG) } \\
22100 \mathrm{~J} \text { (YAG) } \\
18200 \mathrm{~J} \text { (YAG) }\end{array}$ & $\begin{array}{l}4 \\
5 \\
5\end{array}$ & $\begin{array}{c}(72-160) \\
\text { No change } \\
\text { Good PEFR } \\
(90-138)\end{array}$ & $\begin{array}{l}10 \\
\text { Still alive } \\
(21)\end{array}$ \\
\hline 14 & 67 & $\mathrm{~F}$ & Left upper lobe & Radiotherapy & $18700 \mathrm{~J}(\mathrm{YAG})$ & 6 & $\begin{array}{l}\text { Good PEFR } \\
(150-240)\end{array}$ & $\begin{array}{l}\text { Still alive } \\
\text { (17) }\end{array}$ \\
\hline $\begin{array}{l}15 \\
16\end{array}$ & $\begin{array}{l}61 \\
61\end{array}$ & $\begin{array}{l}M \\
M\end{array}$ & $\begin{array}{l}\text { Carina } \\
\text { Carina }\end{array}$ & $\begin{array}{l}\text { Radiotherapy } \\
\text { Radiotherapy }\end{array}$ & $\begin{array}{l}12000 \mathrm{~J}(\mathrm{YAG}) \\
56000 \mathrm{~J}(\mathrm{YAG})\end{array}$ & $\begin{array}{l}3 \\
7\end{array}$ & $\begin{array}{l}\text { Partial } \\
\text { Good PEFR }\end{array}$ & $\begin{array}{l}\text { Still alive (12) } \\
\text { Still alive (12) }\end{array}$ \\
\hline $\begin{array}{l}17 \\
18\end{array}$ & $\begin{array}{l}59 \\
71\end{array}$ & $\stackrel{\mathrm{F}}{M}$ & $\begin{array}{l}\text { Trachea } \\
\text { Right main bronchus }\end{array}$ & Radiotherapy & $\begin{array}{l}11500 \mathrm{~J}(\mathrm{YAG}) \\
\mathrm{NA}^{*}(\mathrm{MBB} \mathrm{YAG})\end{array}$ & $\begin{array}{l}3 \\
2\end{array}$ & $\begin{array}{l}\text { Partial } \\
\text { Good VC } \\
(1 \cdot 75-3 \cdot 40)\end{array}$ & $\begin{array}{l}\text { Still alive (4) } \\
\text { Still alive (4) }\end{array}$ \\
\hline 19 & 61 & $\mathrm{~F}$ & Right main bronchus & - & NA* (MBB YAG) & 2 & $\begin{array}{c}\text { Good PEFR } \\
(60-108)\end{array}$ & Still alive (2) \\
\hline \multicolumn{9}{|c|}{ Patients with complete obstruction of main bronchus } \\
\hline $\begin{array}{l}20 \\
21 \\
22 \\
23 \\
24 \\
25 \\
26 \\
27 \\
28\end{array}$ & $\begin{array}{l}67 \\
64 \\
74 \\
71 \\
57 \\
69 \\
61 \\
71 \\
75\end{array}$ & $\begin{array}{l}F \\
M \\
F \\
F \\
F \\
M \\
M \\
F \\
M\end{array}$ & $\begin{array}{l}\text { Right main bronchus } \\
\text { Right main bronchus } \\
\text { Right main bronchus } \\
\text { Right main bronchus } \\
\text { Right main bronchus } \\
\text { Left main bronchus } \\
\text { Left main bronchus } \\
\text { Left main bronchus } \\
\text { Left main bronchus }\end{array}$ & $\begin{array}{l}\text { Radiotherapy } \\
\text { Chemotherapy } \\
\text { Radiotherapy } \\
\text { Radiotherapy } \\
\text { Radiotherapy } \\
\text { Radiotherapy }\end{array}$ & $\begin{array}{c}200 \mathrm{~J}(\mathrm{~A}) \\
1100 \mathrm{~J}(\mathrm{~A}) \\
2900 \mathrm{~J}(\mathrm{~A}) \\
1600 \mathrm{~J}(\mathrm{~A}) \\
6000 \mathrm{~J}(\mathrm{~A}) \\
6118 \mathrm{~J}(\mathrm{YAG}) \\
10300 \mathrm{~J} \text { (YAG) } \\
6100 \mathrm{Y}(\mathrm{YAG}) \\
\mathrm{NA}^{*} \text { (MBB YAG) }\end{array}$ & $\begin{array}{l}2 \\
3 \\
8 \\
3 \\
5 \\
6 \\
4 \\
3 \\
2\end{array}$ & $\begin{array}{l}\text { Re-expansion } \\
\text { Re-expansion } \\
\text { Partial } \\
\text { Re-expansion } \\
\text { No change } \\
\text { No change } \\
\text { No change } \\
\text { No change } \\
\text { No change }\end{array}$ & $\begin{array}{c}20 \\
3 \\
20 \\
3 \\
12 \\
\text { Still alive }(60) \\
3 \\
3 \\
3\end{array}$ \\
\hline \multicolumn{9}{|c|}{ Patients in whom haemoptysis was presenting symptom } \\
\hline $\begin{array}{l}29 \\
30\end{array}$ & $\begin{array}{l}73 \\
79\end{array}$ & $\begin{array}{l}M \\
M\end{array}$ & $\begin{array}{l}\text { Left upper lobe } \\
\text { Left lower lobe }\end{array}$ & Radiotherapy & $\begin{array}{l}750 \mathrm{~J}(\stackrel{\mathrm{A})}{\mathrm{A}}) \\
1300 \mathrm{JAG})\end{array}$ & $\begin{array}{l}3 \\
3\end{array}$ & $\begin{array}{l}\text { No change } \\
\text { Controlled } \\
\text { (8 weeks) }\end{array}$ & Still alive (40) \\
\hline 31 & 76 & M & Left upper lobe & Radiotherapy & $940 \mathrm{~J}(\mathrm{YAG})$ & 1 & $\begin{array}{l}\text { Controlled } \\
(8 \text { weeks })\end{array}$ & 8 \\
\hline 32 & 77 & $M$ & Left main bronchus & Radiotherapy & $20000 \mathrm{~J}(\mathrm{YAG})$ & 4 & $\begin{array}{c}\text { Controlled } \\
(25 \text { weeks })\end{array}$ & Still alive (25) \\
\hline 33 & 70 & M & Left lower lobe & Radiotherapy & $240 \mathrm{~J}$ & 1 & $\begin{array}{l}\text { Controlled } \\
(5 \text { weeks) }\end{array}$ & Still alive (8) \\
\hline 34 & 59 & $M$ & Left main bronchus & Radiotherapy & $\mathrm{NA}^{*}(\mathrm{MBB}$ laser $)$ & 1 & $\begin{array}{c}\text { Controlled } \\
\text { (3 weeks) }\end{array}$ & 3 \\
\hline
\end{tabular}


Treatment removed the obstruction and the lung re-expanded; he developed an overwhelming infection in the expanded lung, however, and died a week later.

\section{HAEMOPTYSIS}

In three of the six patients haemoptysis was relieved for a minimum of eight weeks.

Case history (case No 30) - A 79 year old man had persistent haemoptysis from a squamous cell carcinoma of the left lower lobe. Radiotherapy had been given without effect. After treatment haemoptysis was relieved for two months and when relapse occurred a further two months' remission followed a second course of treatment.

\section{SURVIVAL}

The mean survival time of the patients who responded was 16 weeks (mean follow-up 53 weeks), and of those who failed to respond it was 12 weeks (mean follow-up 63 weeks). There was no significant difference between either the survival times or the follow-up periods in these two groups.

\section{COMPLICATIONS}

Apart from the two cases of pneumonia after re-expansion, complications were minor. Most patients tolerated treatment extremely well and recovered as rapidly as after a routine diagnostic bronchoscopy; all patients were, however, kept in hospital at least overnight as a precaution. One episode of stridor occurred after treatment. Repeat bronchoscopy revealed a combination of oedema and debris, which was sucked out. Instillation of $1 / 1000$ adrenaline solution through the bronchoscope controlled the oedema. One patient developed complete collapse of the left lung after treatment of the growth in the left main bronchus. The bronchus was blocked by exudate from the burnt area. At the subsequent treatment session the exudate was removed, an adequate lumen obtained, and the lung re-expanded.

\section{Discussion}

Our technical expertise in fibreoptic laser treatment of bronchial carcinoma is clearly inferior to that of other workers abroad, particularly the French, ${ }^{6-8}$ who prefer to use the rigid bronchoscope and have reported large series. Nevertheless, these, and Japanese workers, ${ }^{9-11}$ have not always given full details of follow-up or recorded the effect of treatment on lung function, so that it is difficult to be certain whether laser treatment was indicated or effective in individual patients. Survival figures have sometimes been quoted but, as seen in our own study, have little meaning without comparison with those of an untreated group. Our main interest was therefore to determine whether laser treatment had any value as palliation when other treatments had failed. Palliation is not easily measured but we submit that the tests we used were as objective as possible.

In our study good palliation was obtained in just over half of the cases of partial obstruction of the trachea or a main bronchus but with much the best results when the trachea or main carina was the site of obstruction (fig 2). Re-expansion of the collapsed lung was achieved, after several treatments, in some cases, but with considerable risk of pneumonia in the re-expanded lung. Although this group was of prime interest to us at the beginning of our studies, it soon proved to be the most difficult to treat effectively. Removal of obstructing tumour is difficult without damage to the bronchial wall, which is not easily visualised, and the anatomy is distorted by the surrounding tumour. Growth must therefore be removed in several sessions to ensure that a correct path is being cut through the tumour. Moreover, no radiological method can define the extent of the tumour after total collapse; it may have destroyed the bronchial walls and invaded the collapsed lung to an extent where re-expansion of the useful lung is impossible. It is therefore desirable to treat patients before total collapse has occurred and, in cases of long- standing collapse, it may be wiser to leave the obstructed bronchus alone and concentrate on keeping the other main bronchus clear of tumour.

Haemoptysis was controlled at least partly in several patients. While a complete cure was probably never achieved, it was controlled for at least two months, in most cases after a single treatment. Repeat treatments at two-monthly intervals to control haemoptysis would seem to be effective and worthwhile.

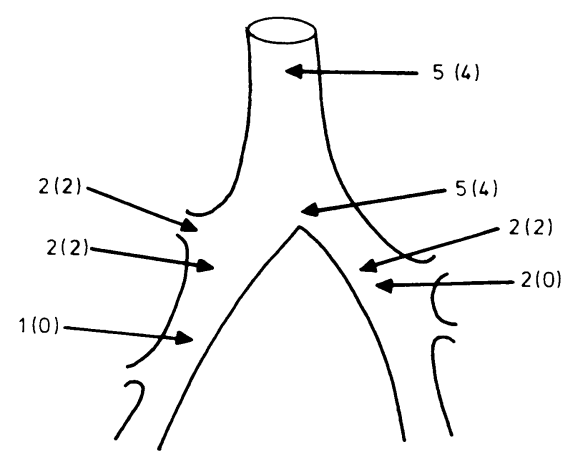

FIG 2-Sites of lesions in 19 patients with partial obstruction. Numbers in parenthesis indicate those who improved with laser treatment.

From the patient's viewpoint laser treatments are similar to a routine bronchoscopy. The procedure was better tolerated than radiotherapy or chemotherapy. Apart from the problem of infection in re-expanded lungs, there was little morbidity. One patient died during treatment. This patient had been treated on nine occasions with good palliation for three months. Treatment was given on the final occasion in an attempt to relieve distressing dyspnoea: airways obstruction at this stage was mainly due to extrinsic compression.

When laser treatment failed, it did not appear to make patients any worse and therefore seems to have been a reasonable "gamble" for these desperate patients, at least half of whom we were able to help. Repeated treatments were, however, required and this reduced the patients' quality of life through time spent in hospital. The main reasons for this were fibre problems and production of exudate, which has been noted by other workers. ${ }^{12}$ The fibre systems used were developed for use in gastrointestinal haemorrhage where only lower energies are required for photocoagulation. Tumour destruction needs much greater energies; some 10-20000 joules may be required to clear the average bronchial tumour. Fibre fatigue is a major problem with these high doses. The gas scavenging system is not fully effective, and valuable time is lost during treatments withdrawing the fibre system and cleaning it. The metal ferrule surrounding the tip may become overheated, resulting in swelling of the plastic cannula so that the catheter system cannot be withdrawn from the bronchoscope. Continued use tends to break down the glue holding the ferrule. We find that fibres rarely last beyond $15000 \mathrm{~J}$ without re-cutting. Further development by the manufacturers is crucial to the future success of laser treatment in respiratory medicine. The usefulness of laser treatment through the bronchoscope is not yet fully realised; if the technical problems could be overcome, there is no doubt that fewer treatments would be required to control the patients' symptoms.

Rigid bronchoscopy has the advantage that the larger biopsy forceps may be used to remove pieces of burnt tumour and suction is more efficient. Under general anaesthesia and muscle relaxants Toty et $a l^{7}$ have shown that treatment is technically much easier, but these patients are poor candidates for general anaesthesia and there is a small but definitive operative mortality with this technique.

Gardner et $a l^{13}$ have used neodynium yttrium aluminium garnet lasers in animal studies and suggest that, beyond a 
threshold dose, laser irradiation has an inhibitory effect on tumour growth as opposed to its simple thermal effect. Our experience suggests, however, that this potential "cure" cannot be achieved in clinical practice. Simple laser irradiation, as opposed to laser irradiation after previous photosensitisation of tumour tissue with haematoporphyrin dye, ${ }^{12}$ therefore holds little hope of cure except, perhaps, in rare instances of slowgrowing polypoid tumours within the bronchial lumen. Surgery, however, is the treatment of choice for such growths.

We thank Dr T Northfield, Dr P Salmon, Dr R Vicary, and Mr J Kirkham for inviting us to join them in use of laser facilities at our three hospitals. The study is supported by a grant from the Office of the Chief Scientist, Department of Health and Social Security.

Correspondence and requests for reprints should be sent to Dr F J C Millard at St James's Hospital, Balham, London SW12 8HW.

\section{References}

${ }^{1}$ Karnofsky DA, Burchenal JH. The clinical evaluation of chemotherapeutic agents in cancer. In: MacLeod C, ed. Evaluation of chemotherapeutic agents. New York: Columbia University Press, 1948.

${ }^{2}$ Medical Research Council. Questionnaire on respiration symptoms. London: Medical Research Council, 1966.

${ }^{3}$ Denison DM, Waller JF, Turton CWG, Sopwith T. Does the lung work ? Breathing in and breathing out. BrF Dis Chest 1982;76:237-53.

4 Butland RJA, Pang JA, Gross ER, Woodcock AA, Geddes DM. Two-, six-, and 12-minute walking tests in respiratory disease. $\mathrm{Br} M e d \mathcal{f} 1982$; 284:1607-8.
${ }^{5}$ Brown SG, Salmon PR, Kelly DF, et al. Argon laser photocoagulation in the dog's stomach. Gut $1979 ; 20: 680-7$.

6 Vourc'h G, Tanniers ML, Toty L, Personne C. Anaesthetic management of tracheal surgery using the neodynium-yttrium-aluminium-garnet laser. Br F Anaesth 1980;52:993-7.

' Toty L, Personne C, Colchen A, Vourc'h G. Bronchoscopic management of tracheal lesions using the neodynium-yttrium-aluminium-garnet laser. Thorax $1981 ; \mathbf{3 6}: 175-8$.

${ }^{8}$ Dumon JF, Reboud E, Garbe L, Aucomte F, Meric B. Treatment of tracheobronchial lesions by laser photoresection. Chest $1982 ; 81: 278-84$.

${ }^{9}$ Oko K, Ohtani T, Amemiya R, et al. Laser surgery in the trachea and bronchus via the fibreoptic bronchoscope [Abstract]. In: Atsumi K, Nimsakul N, eds. Proceedings of 4th congress of International Society for Laser Surgery, Tokyo, November 1981. Tokai University, Kanagawa: International Society for Laser Surgery, 1981:16-9.

10 Yamada R, Amemiya R, Ohtani $T$, et al. Indications and complications of Nd-YAG laser surgery via the fibreoptic bronchoscope in cases involving the trachea and major bronchi [Abstract]. In: Atsumi K, Nimsakul N, eds. Proceedings of 4th congress of International Society for Laser Surgery, Tokyo, November 1981. Tokai University, Kanagawa: International Society for Laser Surgery, 1981:21-4.

11 Tamada J, Ito $M$, Teramatsu $T$. Clinical study of bronchofibrescopic Nd-YAG laser surgery [Abstract]. In: Atsumi K, Nimsakul N, eds. Proceedings of 4th congress of International Society for Laser Surgery, Tokyo, November 1981. Tokai University, Kanagawa: International Society for Laser Surgery, $1981: 13-5$.

12. Hayata Y, Kato H, Konaka C, Ono J, Takizawa N, Kato W. Haematoporphyrin derivative and laser photoirradiation in the treatment of lung cancer. Chest $1982 ; 81: 269-77$.

${ }^{13}$ Gardner W, Hugh-Jones P, Carroll MA, Hewitt ER, Hewitt HB, Whimster W. Quantitative analysis of effect of neodynium-YAG laser on transplanted mouse carcinomas. Thorax $1982 ; 37: 594-7$.

(Accepted 12 November 1982)

\title{
Increased incidence of malignancy in dermatitis herpetiformis
}

\author{
J N LEONARD, W F G TUCKER, J S FRY, CARMEL A E COULTER, A W BOYLSTON, \\ R M H MCMINN, G P HAFFENDEN, A F SWAIN, LIONEL FRY
}

\begin{abstract}
A retrospective study of 109 patients with dermatitis herpetiformis showed that malignant tumours had developed in seven patients, the expected incidence being 2.93 , giving a relative risk of 2.38 . In three of the seven patients the malignancy was a lymphoma, giving a relative risk of 100 for this tumour (expected incidence 0.03). In six of the seven patients who developed malignancies small-intestinal biopsy specimens were macroscopically abnormal, giving a relative risk of 4.22 in this
\end{abstract}

St Mary's Hospital, London W2 1NY

J N LEONARD, $M B$, MRCP, honorary senior registrar, dermatology department

W F G TUCKER, MB, MRCP, registrar, dermatology department

CARMEL A E COULTER, MRCP, FRCR, consultant, radiotherapy department

G P HAFFENDEN, FIMLS, senior chief medical laboratory scientific officer, histopathology department

A F SWAIN, MB, MRCP, senior registrar, dermatology department

LIONEL FRY, MD, FRCP, consultant, dermatology department

St Mary's Hospital Medical School, London W2

J S FRY, PHD, lecturer, epidemiology department

A W BOYLSTON, MD, MRCPATH, senior lecturer, histopathology department

Anatomy Department, Institute of Basic Medical Sciences, Royal College of Surgeons of England, London WC2

R M H MCMINN, MD, PHD, emeritus professor group, which is similar to that reported in adult coeliac disease. Patients treated with a gluten-free diet appeared to have a reduced risk of developing malignancy compared with those taking a normal diet (relative risk with gluten-free diet 1.01 and with normal diet 3.09). A small subgroup of eight patients with linear IgA dermatitis herpetiformis were also studied: three developed malignant disease and in one the tumour was a lymphoma.

\section{Introduction}

An increased incidence of malignant disease, particularly lymphoma, has been reported in patients with adult coeliac disease. ${ }^{1-3}$ Most patients with dermatitis herpetiformis have an associated gluten-sensitive enteropathy. ${ }^{45}$ Although there have been isolated reports of small-intestinal lymphoma in individual patients with dermatitis herpetiformis, ${ }^{6-8}$ the incidence of malignancy in this condition has not been reported. We undertook a study to determine whether there is an increased incidence of malignant disease in dermatitis herpetiformis and, if so, any predisposing factors.

\section{Patients and methods}

One hundred and nine patients who had been followed up in the dermatitis herpetiformis clinic at St Mary's Hospital since 1969 were included in the study. Dermatitis herpetiformis was diagnosed on the basis of clinical presentation, response of the rash to sulphones, 